\title{
FUZZY ESTIMATION OF ACTIVITIES DURATION IN CONSTRUCTION PROJECTS
}

\begin{abstract}
N. IBADOV 1
During implementation of construction projects, durations of activities are affected by various factors. Because of this, both during the planning phase of the project as well as the construction phase, managers try to estimate, or predict, the length of any delays that may occur. Such estimates allow for the ability to take appropriate action in terms of planning and management during the execution of construction works. This paper presents the use of the non-deterministic concept for describing the uncertainty of estimating works duration. The concept uses the theory of fuzzy sets. The author describes a method for fuzzy estimations of construction works duration based on the fact that uncertain data is an inherent factor in the conditions of construction projects. An example application of the method is presented. The author shows a fuzzy estimation for the duration of an activity, taking into consideration the distorting influence caused by malfunctioning construction equipment and delivery delays of construction materials.
\end{abstract}

Keywords: construction delays, fuzzy sets, fuzzy logic, fuzzy rules, delay factors

\section{INTRODUCTION}

During construction (objects implementation), work activities are vulnerable to various distorting factors which can include weather conditions, delays in delivery of materials, equipment malfunctions, capability of the workers, improper organization of works on site, etc. [4]. Despite the fact that planners are aware of these factors, sometimes they do not take them into consideration while estimating the duration of activities at the designing stage. As a result, estimated durations of activities and actual durations on construction sites differ.

\footnotetext{
${ }^{1}$ PhD., Eng., Warsaw University of Technology, Faculty of Civil Engineering, Al. Armii Ludowej 16, 00-637 Warsaw, Poland, e-mail: n.ibadov@il.pw.edu.pl
} 
Meanwhile, these factors should not only be identified, but the right conditions for the execution of construction works should be prepared. These conditions should include possible preventive measures [6].

One has to bear in mind that even the planner with expert knowledge about distorting factors and their consequences is characterized by approximation and uncertainty. In this case the possible consequences of various events are known (whether favourable or unfavourable for the completion of the construction project) but the probability distributions for these events are unknown; and when one is trying to estimate the duration of activities, the problems arise. It is impossible to use statistical methods and probabilistic measures to assess outcomes of various scenarios in which various factors affect the course of the construction process [5]. In this case it is worth it to consider the use of fuzzy logic and fuzzy set theory, which are perfect for describing problems in which a strict quantitative assessment cannot be applied [12]. In this article, the author presents the basics of the fuzzy set theory and its applications for determining the duration of construction activities by estimating possible delays.

\section{FUNDAMENTAL CONCEPTS OF THE FUZZY SETS THEORY}

A fuzzy set $A$ in a non-empty space $\mathrm{X}$ is a set of pairs:

$$
A=\left\{\left(x, \mu_{A}(x)\right) ; x \in \mathrm{X}\right\}
$$

where:

$$
\mu_{A}: \mathrm{X} \rightarrow[0,1]
$$

is a membership function of the fuzzy set $A \subseteq \mathrm{X},[10]$. For each element $x \in \mathrm{X}$, this function assigns a degree of membership to the fuzzy set A. Depending on the value of the membership degree, one can distinguish three cases:

1) $\mu_{A}(x)=1$ means that element $\mathrm{x}$ is fully included in fuzzy set $\mathrm{A}, x \in A$,

2) $\mu_{A}(x)=0$ means that element $\mathrm{x}$ is not included in fuzzy set $\mathrm{A}, x \notin A$,

3) $0<\mu_{A}(x)<1$ means that element $\mathrm{x}$ is partially included (fuzzy member) in fuzzy set A. 
Operations on fuzzy sets A and B such as standard intersection $(\cap)$ and standard union $(\cup)$, can be displayed in the following manner, [2], [7]:

$$
\begin{aligned}
& \mu_{A \cap B}(x)=\min \left(\mu_{A}(x) \mu_{B}(x)\right), \forall x \in \mathrm{X}, \\
& \mu_{A \cup B}(x)=\max \left(\mu_{A}(x) \mu_{B}(x)\right), \forall x \in \mathrm{X} .
\end{aligned}
$$

Fuzzy relation $R \subseteq \mathrm{X} \times \mathrm{Y}$ between two non-empty sets $\mathrm{X}$ and $\mathrm{Y}$ is a fuzzy set defined in the Cartesian product $\mathrm{X} \times \mathrm{Y}$ :

$$
R=\left\{\left((x, y), \mu_{R}(x, y)\right)\right\}, \quad \forall x \in \mathrm{X}, \forall y \in \mathrm{Y}
$$

where:

$$
\mu_{R}: \mathrm{X} \times \mathrm{Y} \rightarrow[0,1]
$$

is a membership function. This function assigns to each pair $(x, y), x \in \mathrm{X}, y \in \mathrm{Y}$ its degree of membership $\mu_{R}(x, y)$, which is interpreted as a strength of association between elements $x \in \mathrm{X}$ and $y \in \mathrm{Y},[10]$.

Let us take into consideration three non-fuzzy sets $\mathrm{X}, \mathrm{Y}$ and $\mathrm{Z}$ and two fuzzy relations: $R \subseteq \mathrm{X} \times \mathrm{Y}$ with a membership function $\mu_{R}(x, y)$ and $U \subseteq \mathrm{Y} \times \mathrm{Z}$ with a membership function $\mu_{U}(y, z)$. If set $\mathrm{Y}$ has a finite number of elements, then the composition of fuzzy relations $R \subseteq \mathrm{X} \times \mathrm{Y}$ and $U \subseteq \mathrm{Y} \times \mathrm{Z}$ is called a fuzzy relation $V=R \circ U$ and it has a form of two-dimensional fuzzy set membership function [10]:

$$
\mu_{R o U}(x, z)=\max _{y \in Y}\left\{\min \left\{\mu_{R}(x, y), \mu_{U}(y, z)\right\}\right\}
$$

Another very important feature of fuzzy sets is that they can be used for inference, which uses linguistic variables. 
The general scheme of inference, recorded in the form of fuzzy rules is as follows [11]:

$$
\text { IF" logical premise" THEN " conclusion" }
$$

An important problem is a method of creating the appropriate rules of inference. One of the solutions is to use the knowledge and experience of an expert. Drawing fuzzy conclusions and converting them into a quantitative assessment is carried out on the basis of causal fuzzy rules and relations. It is assumed that A is a fuzzy set in the space of premises X, and B is an impact level of a factor (i.e. high impact) in conclusion space Y. The fuzzy set that describes the impact level of a factor in space $\mathrm{X}$ is denoted by A', and the fuzzy set which describes the probability level is denoted by B'. Then the causal fuzzy relation $A \rightarrow B$ of premise and conclusion, which reflects the expert's knowledge, is called the fuzzy rule $\mathrm{R}$ :

$$
R=A \rightarrow B
$$

So the process of obtaining the fuzzy conclusion B' with the use of knowledge $A \rightarrow B$ and data A' can be represented as follows:

$$
B^{\prime}=A^{\prime} \circ R=A^{\prime} \circ(A \rightarrow B)=\max \left\{\min \left(\mu_{A^{\prime}}(x), \mu_{R}(x, y)\right)\right\}
$$

where $\mu_{A^{\prime}}(x)$ and $\mu_{R}(x, y)$ are membership functions of respectively fuzzy set $\mathrm{A}^{\prime}$ and $\mathrm{R}$.

\section{FUZZY ESTIMATION OF ACTIVITIES' DURATIONS}

In this article, in order to determine activities' (construction works) durations, fuzzy rules and relations were used. Necessary operations on fuzzy sets were conducted in accordance with Eq. (2.3), (2.4), (2.7) and (2.10).

Let us assume that based on the effort norms, a duration of an activity (nominal time) was assumed, for example: $t_{n}=20$ working shifts. One needs to specify the expected duration of the activity and take into account the distorting influence caused by delays in deliveries of construction materials and malfunctioning construction equipment. 
Let the rules appropriate for the considered case take the following forms:

$\mathbf{R}_{1}^{\mathbf{I}}$ : IF activity's sensitivity to delays in construction materials deliveries is "medium" AND frequency of delays in construction materials deliveries is "medium" THEN the range of distortions for activity is "high".

$\mathbf{R}_{2}{ }_{2}$ : IF activity's sensitivity to delays caused by malfunction of construction equipment is "very high" AND malfunction of construction equipment frequency is "high" THEN the range of distortions for activity is "very high".

In the next step, the relation between the scope of distortions for an activity's assessment, and an activity's delay time is determined. Let the rules appropriate for the considered case take the following forms:

$\mathbf{R}^{\mathrm{II}}$ : IF the range of distortions for activity is "high" THEN activity's delay time value is "high".

$\mathbf{R}^{\text {II }}$ : IF the range of distortions for activity is "very high" THEN activity's delay time value is "very high".

The activity's sensitivity to delays, the frequency of distortion factors and the scope of distortions for an activity can be described in fuzzy set notation as follows:

$$
\begin{aligned}
& \text { medium }=\{0,3 / 0,1 ; 0,4 / 0,7 ; 0,5 / 1,0 ; 0,6 / 0,7 ; 0,7 / 0,1\} \\
& \text { high }=\{0,5 / 0,0 ; 0,6 / 0,5 ; 0,7 / 0,9 ; 0,9 / 0,5 ; 1,0 / 0,0\} \\
& \text { very high }=\{0,7 / 0,0 ; 0,8 / 0,1 ; 0,9 / 0,7 ; 1,0 / 1,0\}
\end{aligned}
$$

Creation of fuzzy relation $R \subseteq \mathrm{X} \times \mathrm{Y}$ on the basis of rules $\mathrm{R}_{1}^{\mathrm{I}}$ and $\mathrm{R}_{2}^{\mathrm{I}}$ proceeds as follows:

a) first, with the use of Eq. (2.3) and (2.5) fuzzy relation $R_{1} \subseteq \mathrm{X}_{1} \times \mathrm{Y}_{1}$ is created, where:

$\mathrm{X}_{1}$ - a subset ofdelays in construction materials deliveries frequency point assessments. Referred to as: "medium",

$\mathrm{Y}_{1}$ - a subset of the scope of distortions for activity point assessments. Referred to as: "high", 
b) then, with the use of Eq. (2.3) and (2.5) fuzzy relation $R_{2} \subseteq \mathrm{X}_{2} \times \mathrm{Y}_{2}$ is created, where: $\mathrm{X}_{2}$ - a subset of malfunction of construction equipment frequency point assessments. Referred to as: "high",

$\mathrm{Y}_{2}$ - a subset of the scope of distortions for activity point assessments. Referred to as: "very high",

c) by composition of fuzzy relations $R_{1} \subseteq \mathrm{X}_{1} \times \mathrm{Y}_{1}$ and $R_{2} \subseteq \mathrm{X}_{2} \times \mathrm{Y}_{2}$ with the use of Eq. (2.4), one can receive fuzzy relation $R=R_{1} \cup R_{2}$.

Creation of fuzzy relation $U \subseteq \mathrm{Y} \times \mathrm{Z}$ on the basis of rules $\mathrm{R}^{\mathrm{II}}$ and $\mathrm{R}_{2}^{\mathrm{II}}$ proceeds in similar manner:

a) first, with the use of Eq. (2.3) and (2.5) fuzzy relation $U_{1} \subseteq \mathrm{Y}_{1} \times \mathrm{Z}_{1}$ is created, where:

$\mathrm{Y}_{1}$ - a subset of the scope of distortions for activity point assessments. Referred to as: "high", $\mathrm{Z}_{1}$ - a subset of activity's delay time values point assessments. Referred to as: "high",

b) then, with the use of Eq. (2.3) and (2.5) fuzzy relation $U_{2} \subseteq \mathrm{Y}_{2} \times \mathrm{Z}_{2}$ is created, where:

$\mathrm{Y}_{2}$ - a subset of the scope of distortions for activity point assessments. Referred to as: "very high", $\mathrm{Z}_{2}$ - a subset of activity's delay time values point assessments. Referred to as: "very high",

c) by composition of fuzzy relations $U_{1} \subseteq \mathrm{Y}_{1} \times \mathrm{Z}_{1}$ and $U_{2} \subseteq \mathrm{Y}_{2} \times \mathrm{Z}_{2}$ with the use of Eq. (2.4), one can receive fuzzy relation $U=U_{1} \cup U_{2}$.

Possible activity's delay times can be described in fuzzy set notation as follows:

$$
\begin{aligned}
& \text { high }=\{5 / 0,5 ; 7 / 0,9 ; 9 / 0,9 ; 11 / 0,5 ; 13 / 0,0\} \\
& \text { very high }=\{5 / 0,0 ; 7 / 0,0 ; 9 / 0,1 ; 11 / 0,7 ; 13 / 1,0\}
\end{aligned}
$$

The result of fuzzy relations $R$ and $U$ composition with the use of Eq. (2.7) is shown in Table 1 in the form of two-dimensional fuzzy set $V=R \circ U$.

The composition of fuzzy relations $R$ and $U$ allows for direct linking of activity delay time values assessment and various distortion factors occurrence frequency assessment. 
Table 1. Membership coefficient matrix $V=R \circ U$

\begin{tabular}{|c|c|c|c|c|c|}
\hline \multirow{2}{*}{$\begin{array}{c}\text { Set } \mathbf{X} \text { : occurrence frequency point } \\
\text { assessment, for distortion caused by given } \\
\text { factor, } x\end{array}$} & \multicolumn{5}{|c|}{$\begin{array}{c}\text { Set } \mathbf{Z}: \\
\text { Possible activities' delays, } z \text {, [working shifts] }\end{array}$} \\
\hline & $z_{1}=5$ & $z_{2}=7$ & $z_{3}=9$ & $z_{4}=11$ & $z_{5}=13$ \\
\hline 0,0 & 0 & 0 & 0 & 0 & 0 \\
\hline 0,1 & 0 & 0 & 0 & 0 & 0 \\
\hline 0,2 & 0 & 0 & 0 & 0 & 0 \\
\hline 0,3 & 0 & 0 & 0 & 0 & 0 \\
\hline 0,4 & 0 & 0 & 0 & 0 & 0 \\
\hline 0,5 & 0 & 0 & 0 & 0 & 0 \\
\hline 0,6 & 0,5 & 0,7 & 0,7 & 0,5 & 0,5 \\
\hline 0,7 & 0,5 & 0,7 & 0,5 & 0,7 & 0,9 \\
\hline 0,8 & 0,5 & 0,5 & 0,5 & 0,7 & 0,9 \\
\hline 0,9 & 0,5 & 0,5 & 0,5 & 0,5 & 0,5 \\
\hline 1,0 & 0 & 0 & 0 & 0 & 0 \\
\hline
\end{tabular}

Two-dimensional fuzzy set $V=R \circ U$ can be used to determine the parameters of the activity's delay probability distribution (expected value and standard deviation), [8], [9]. In the matrix of two-dimensional fuzzy set $V=R \circ U$ membership coefficients, one can identify a row, for which the product of the sum for membership coefficients values $\mu_{R \circ U}\left(x, z_{k}\right)$ and distortion occurrence frequency point assessment reaches a maximum. Then, based on the values of membership coefficients $\mu_{R \circ U}\left(x, z_{k}\right)$ in the row, one can determine:

1) the probability that the increase in delay will have a specific value $z_{k}$ :

$$
\mathrm{P}\left(z=z_{k}\right)=\frac{\mu_{R \circ U}\left(x, z_{k}\right)}{\sum_{k=1}^{K} \mu_{R \circ U}\left(x, z_{k}\right)},
$$

2) expected activity's delay time:

$$
\mathrm{E}(z)=\sum_{k=1}^{K}\left\{\left(z_{k}\right) \cdot \mathrm{P}\left(z=z_{k}\right)\right\}
$$


3) standard deviation of the expected activity's delay time:

$$
\sigma_{z}=\sqrt{\sum_{k=1}^{K}\left\{\left(z_{k}\right)^{2} \cdot \mathrm{P}\left(z=z_{k}\right)\right\}-\mathrm{E}^{2}(z)} .
$$

In the presented example, one can determine that the product of the sum for membership coefficients values $\mu_{R o U}(x, z)$ and the delay frequency estimation reaches the maximum (a row with delay frequency level that equals 0,8 ) for data shown in Table 1. With use of Eq. (3.6), (3.7) and (3.8) the following results can be obtained:

$$
\begin{aligned}
& \mathrm{P}(\mathrm{z}=5)=0,5 / 3,1=0.16, \\
& \mathrm{P}(\mathrm{z}=7)=0,5 / 3,1=0.16, \\
& \mathrm{P}(\mathrm{z}=9)=0,5 / 3,1=0.16, \\
& \mathrm{P}(\mathrm{z}=11)=0,7 / 3,1=0.23, \\
& \mathrm{P}(\mathrm{z}=13)=0,9 / 3,1=0.29, \\
& \mathrm{E}(\mathrm{z})=9,66 \text { days, } \\
& \sigma_{\mathrm{z}}=2,88 \text { days. }
\end{aligned}
$$

Results could be used for calculations of the expected time of relevant activity performance by adding the expected duration of activity and delay:

$$
E(t)=t_{n}+E(z)=20+9,66=29,66 .
$$

\section{CONCLuSions}

The calculated delay value for a particular activity gives information about the range of delays. Reliable knowledge on the possibility of the considered factors' occurrence and their effects is crucial in terms of accuracy and relevance of delay estimation. Fuzzy relations allow for the consideration of various factors' negative effect on duration of construction works.

Fuzzy logic and fuzzy relations allow for consideration of connections between possible activity's delay time and its sensitivity to given distortion factors, frequency of factor occurrences and subjectively assessed impact of the factor on duration of activity. Presented examples show the usefulness of the method for estimating duration of activities on the basis 
of incomplete/uncertain data (a situation common in construction projects). In this respect, the set fuzzy theory is a tool that helps to describe the uncertainty. Fuzzy relations allow for the estimation of activities (construction works) and delays, taking expert knowledge into consideration. The presented method can be useful both for updating the project's schedule during construction works as well as for scheduling at the design stage of a construction project.

\section{REFERENCES}

1. Ayyub B. M., Haldar A.: Project scheduling using fuzzy set concepts, Journal of Construction Engineering and Management, 110(2), 1984, 189-204.

2. Czogała E., Pedrycz W.: Elementy i metody teorii zbiorów rozmytych, PWN, Warszawa 1985.

3. Dubois D., Prade H.: Fuzzy sets and statistical data, European Journal of Operational Research, 25, 1986, 345-256.

4. Ibadov N.: Wykorzystanie teorii zbiorów rozmytych do podejmowania decyzji w budownictwie, Konferencja naukowo-techniczna: „Sterowanie procesami inwestycyjnymi w budownictwie wodnym i morskim”. SzczecinMiędzyzdroje, 17-20 czerwca 1999.

5. Ibadov N., Kulejewski J.: Rozmyte modelowanie czasów wykonania robót budowlanych w warunkach niepewności, Czasopismo Techniczne, 107(2), Wydawnictwo Politechniki Krakowskiej, 2010, 139-155.

6. Ibadov N.: Modelowanie czasów wykonania robót budowlanych z wykorzystaniem wnioskowania rozmytego, Czasopismo Logistyka 2010, nr 6, Pełny tekst na CD.

7. Kasprzyk J.: Zbiory rozmyte w analizie systemowej, PWN, Warszawa 1986.

8. Oliveros A. V. O., Fayek A. R.: Fuzzy logic approach for activity delay analysis and schedule updating, Journal of Construction Engineering and Management, ASCE, 131(1), 2005, 42-51.

9. Pan N. F., Hadipriono F. C., Whitlatch E.: A fuzzy reasoning knowledge-based system for assessing rain impact in highway construction scheduling: Part I. Analytical model, Journal of Intelligent and Fuzzy Systems, $16,2005,157-167$.

10. Rutkowska D., Piliński M., Rutkowski L.: Sieci neuronowe, algorytmy genetyczne i systemy rozmyte, PWN, Warszawa - Łódź 1997.

11. Rutkowski L.: Metody i techniki sztuczniej inteligencji, PWN, Warszawa 2006.

12. Zadeh L. A.: Fuzzy Sets, Information and Control, 1965, vol. 8. Pp. 338-353.

\section{LIST OF FIGURES AND TABLES:}

Tab. 1. Membership coefficient matrix $V=R \circ U$

Tab. 1. Macierz współczynników przynależności $V=R \circ U$ 


\section{ROZMYTE SZACOWANIE CZASÓW TRWANIA ROBÓT BUDOWLANYCH}

Slowa kluczowe: opóźnienia czasów wykonania robót, zbiory rozmyte, wnioskowanie rozmyte, reguły rozmyte, czynniki opóźniające budowę

\section{STRESZCZENIE:}

W czasie realizacji obiektów budowlanych, procesy wykonawcze są narażone na wpływ różnych czynników zakłócających (warunki atmosferyczne, nieterminowość dostaw materiałów, awarie sprzętu, kwalifikacje robotników, zła organizacja robót na budowie itp.). Czynniki te, pomimo świadomości planistów o ich istnieniu, nie zawsze są uwzględniane podczas szacowania czasów wykonania robót na etapie projektowania budowy. Powoduje to różnice pomiędzy oszacowaniami czasów wykonania robót a rzeczywistymi czasami wykonania robót, uzyskanymi podczas realizacji budowy. Trzeba mieć na uwadze, że wiedza planisty (eksperta) na temat czynników zakłócających oraz ich konsekwencjach ma charakter przybliżony i niepewny. Kiedy próbuje się oszacować czasy wykonania robót budowlanych, powstaje problem niemożności wykorzystania metod statystycznych i miary probabilistycznej dla oceny skutków realizacji różnych scenariuszy jednoczesnego oddziaływania różnych czynników na przebieg budowy. Warte rozpatrzenia jest w tym przypadku również wykorzystanie logiki rozmytej i teorii zbiorów rozmytych.

W artykule przedstawiono przykład wykorzystania teorię zbiorów rozmytych dla oszacowania rozmytego czasu wykonania roboty budowlanej biorąc pod uwagę wpływy zakłócające spowodowane w skutek awarii sprzętu budowlanego oraz opóźnienia w dostawach materiałów budowlanych.

Według L.A. Zadeha zbiór rozmyty A w przestrzeni X zapisuje się jako zbiór par:

$$
A=\left\{\left(x, \mu_{A}(x)\right) ; x \in X\right\}
$$

gdzie $\mu_{A}: X \rightarrow[0,1]$ nazywa się funkcją przynależności zbioru rozmytego A. Funkcja ta każdemu elementowi $x \in X$ przypisuje jego stopień przynależności do zbioru rozmytego A.

Ważną cechą zbiorów rozmytych jest możliwość ich wykorzystania do wnioskowania. Wyciągnięcia rozmytych wniosków i przeobrażenie ich w ocenę ilościową prowadzi się na podstawie przyczynowo - skutkowych reguł i relacji rozmytych.

Zakłada się, że A jest zbiorem rozmytym w przestrzeni przesłanek X, a B jest poziomem wpływu czynnika w przestrzeni konkluzji Y. Zbiór rozmyty opisujący poziom wpływu czynnika w przestrzeni X oznaczamy przez A', a zbiór rozmyty opisujący poziom prawdopodobieństwa przez B'. Uzyskania rozmytego wniosku B' z wykorzystaniem wiedzy $R=A \rightarrow B$ oraz danych A’ dokonuje się poprzez złożenie:

$$
B^{\prime}=A^{\prime} \circ R=A^{\prime} \circ(A \rightarrow B)=\max \left\{\min \left(\mu_{A^{\prime}}(x), \mu_{R}(x, y)\right)\right\},
$$

gdzie $\mu_{A}(x)$ i $\mu_{R}(x, y)$ są odpowiednimi funkcjami przynależności zbiorów rozmytych A’ i R.

Załóżmy, że na podstawie normatywów pracochłonności został ustalony nominalny czas wykonania pewnej roboty budowlanej, na przykład $t \mathrm{n}=20$ zmian roboczych. Należy określić oczekiwany czas wykonania tej roboty z uwzględnieniem zakłóceń, spowodowanych opóźnieniami w dostawach materiałów budowlanych i awariami sprzętu budowlanego. 
Wtedy reguły rozmyte mają postać:

RI1: JEŻELI wrażliwość roboty na opóźnienia w dostawach materiałów budowlanych jest „średnia” I częstość występowania opóźnień w dostawach będzie „średnia” TO zakres zakłóceń przebiegu roboty będzie „duży”.

RI2: JEŻELI wrażliwość roboty na spowolnienie postępu z powodu wystąpienia awarii sprzętu budowlanego jest „bardzo duża” I częstość występowania awarii sprzętu budowlanego będzie „duża” TO zakres zakłóceń przebiegu robót będzie „,bardzo duży”.

Następnie, ustala się zależność pomiędzy oceną zakresu zakłóceń przebiegu roboty, a wydłużeniem czasu jej wykonania.

Niech odpowiednie reguły dla rozpatrywanego przypadku mają postać:

RII1: JEŻELI zakres zakłóceń przebiegu roboty będzie „duży” TO wydłużenie czasu wykonania roboty będzie „duże”.

RII2: JEŻELI zakres zakłóceń przebiegu roboty będzie „bardzo duży” TO wydłużenie czasu wykonania roboty będzie „bardzo duże”.

Wrażliwość robót na zakłócenia, częstości występowania czynników zakłócających oraz zakres zakłóceń przebiegu robót można opisać w notacji zbiorów rozmytych, jak:

$$
\begin{aligned}
& \text {,średnia” }=\{0,3 / 0,1 ; 0,4 / 0,7 ; 0,5 / 1,0 ; 0,6 / 0,7 ; 0,7 / 0,1\} \text {; } \\
& \text { „duża” = }\{0,5 / 0,0 ; 0,6 / 0,5 ; 0,7 / 0,9 ; 0,9 / 0,5 ; 1,0 / 0,0\} \text {; } \\
& \text { „bardzo duża” }=\{0,7 / 0,0 ; 0,8 / 0,1 ; 0,9 / 0,7 ; 1,0 / 1,0\} \text {. }
\end{aligned}
$$

Możliwe wydłużenia czasu wykonania roboty zaś, jak:

$$
\begin{gathered}
\text { „duże" }=\{5 / 0,5 ; 7 / 0,9 ; 9 / 0,9 ; 11 / 0,5 ; 13 / 0,0\} ; \\
\text { „bardzo duże" }=\{5 / 0,0 ; 7 / 0,0 ; 9 / 0,1 ; 11 / 0,7 ; 13 / 1,0\} .
\end{gathered}
$$

Na podstawie reguł RI1 i RI2 tworzy się relacja rozmyta $R=R_{1} \cup R_{2}$ opisująca przyczynowo - skutkowe zależności tych reguł. Podobny sposób na podstawie reguł RII1 i RII2 tworzy się relacja rozmyta $U=U_{1} \cup U_{2}$.

Złożenie relacji rozmytych $\mathrm{R}$ i U umożliwia bezpośrednie powiązanie oceny wydłużenia czasu wykonania roboty budowlanej $\mathrm{z}$ oceną częstości oddziaływania poszczególnych czynników zakłócających. W macierzy wartości współczynników przynależności do dwuwymiarowego zbioru rozmytego $V=R \circ U$ identyfikuje się wiersz, dla którego iloczyn sumy wartości współczynników przynależności $\mu_{R \circ U}(x, z)$ i oceny punktowej częstości wystąpienia zakłóceń osiąga maksimum.

W przedstawionym przykładzie $\mu_{R \circ U}(x, z)$ uzyskuje wartości $(05 ; 0,5 ; 0,5 ; 0,7 ; 0,9)$ a ocena punktowa częstości wystąpienia zakłóceń wynosi 0,8 . 
Dla przedstawionych wartości prawdopodobieństwo wydłużenia czasu wykonania roboty przyjmie wartości:

$$
\begin{aligned}
& \mathrm{P}_{(\mathrm{z}=5)}=0,5 / 3,1=0.16 ; \\
& \mathrm{P}_{(\mathrm{z}=7)}=0,5 / 3,1=0.16 ; \\
& \mathrm{P}_{(\mathrm{z}=9)}=0,5 / 3,1=0.16 ; \\
& \mathrm{P}_{(\mathrm{z}=11)}=0,7 / 3,1=0.23 ; \\
& \mathrm{P}_{(\mathrm{z}=13)}=0,9 / 3,1=0.29 .
\end{aligned}
$$

Wartość oczekiwana $\mathrm{E}(z)$ i odchylenia standardowe $\sigma_{z}$ wynoszą odpowiednio: 9,66 i 2,88 dni. Oczekiwany czas wykonania roboty zaś wynosi 29,66 dni.

Otrzymana wielkość wydłużenia (opóźnienia) czasu wykonania roboty budowlanej informuje o jego zakresie zmienności. Rzetelna wiedza na temat możliwości zaistnienia rozpatrywanych czynników oraz ich wpływów mają kluczowe znaczenie w zakresie dokładności i trafności oszacowania tego wydłużenia. Zastosowanie relacji rozmytych umożliwiają uwzględnienie skutków negatywnego oddziaływania różnych czynników na czasy wykonania robót budowlanych.

Wykorzystanie wnioskowania rozmytego i relacji rozmytych pozwala na uwzględnienie zależności pomiędzy możliwym wydłużeniem czasu trwania danej roboty a jej wrażliwością na działanie określonych czynników zakłócających, częstością oddziaływania poszczególnych czynników oraz subiektywnie ocenianym wpływem zakłócenia na czas wykonania roboty. Przedstawiona metoda może być przydatna zarówno dla aktualizacji harmonogramu w czasie realizacji budowy jak i dla sporządzania harmonogramów w etapie projektowania budowy. 